\title{
Assessing transformation scenarios from pure Norway spruce to mixed uneven-aged forests in mountain areas
}

\author{
Torben Hilmers $^{1}$ (D) Peter Biber $^{1}$ (D) Thomas Knoke $^{2}$ (D) Hans Pretzsch ${ }^{1}$ (D)
}

Received: 10 September 2019 / Revised: 24 January 2020 / Accepted: 15 February 2020 / Published online: 27 February 2020

(c) The Author(s) 2020

\begin{abstract}
Mixed mountain forests, primarily made up of Norway spruce (Picea abies (L.) Karst.), silver fir (Abies alba Mill.) and European beech (Fagus sylvatica L.), cover about $10 \times 10^{6}$ ha of submontane-subalpine altitudes in Europe. They provide invaluable ecosystem services, e.g. protection against avalanches, landslides or rockfall. However, pure Norway spruce stands have, since mediaeval times, been heavily promoted as productive stand types for salt works at sites naturally supporting mixed mountain forests. Damage to these secondary pure spruce stands has been steadily increasing in recent decades. Furthermore, due to their previous limitation due to low temperatures and a short growing season, forest ecosystems in higher elevations are expected to be strongly affected by climate warming. To address these problems, alternative management concepts are being intensively discussed. A possible option to improve the stability and resilience of the stand is the transformation from pure Norway spruce stands into site-appropriate, sustainable and stable mixed mountain forests. In this study, we have tested seven different transformation scenarios (e.g. slit, shelterwood and gap-coupes, strip clear-cutting, donothing) and their impact on five evaluation criteria (forest growth, economics, carbon sequestration, (stand) stability and biodiversity). As there are hardly any practical examples for some of the transformation scenarios available, we have used the forest growth simulator SILVA to assess whether the tested transformation scenarios differ in transformation success and to observe trade-offs between the criteria of evaluation. Of the investigated scenarios, we consider the ones with gap or slit-coupes with the most beneficial overall utility values for the portfolio of the five evaluation criteria. However, we showed with our results that it is possible, by means of several trajectories, to return destabilised forests to sustainable and stable systems. We showed that a transformation is realistic, even if sophisticated silvicultural concepts are not strictly pursued.
\end{abstract}

Keywords Picea abies (L.) · Pure stands · Transformation · Mixed mountain forests · Evaluation criteria

Communicated by Eric R. Labelle.

Electronic supplementary material The online version of this article (https://doi.org/10.1007/s10342-020-01270-y) contains supplementary material, which is available to authorized users.

Torben Hilmers

torben.hilmers@tum.de

1 Chair for Forest Growth and Yield Science, TUM School of Life Sciences Weihenstephan, Technical University of Munich, Hans-Carl-Von-Carlowitz-Platz 2, 85354 Freising, Germany

2 Institute of Forest Management, TUM School of Life Sciences Weihenstephan, Technische Universität München, Hans-Carl-von-Carlowitz-Platz 2, Freising 85354, Germany

\section{Introduction}

In addition to the often promoted Norway spruce (Picea abies (L.) Karst), mixed mountain forests also comprise silver fir (Abies alba Mill) and European beech (Fagus sylvatica L.). In the following, we refer to these tree species as spruce, fir and beech, respectively: They can successfully coexist in altitudes between $\sim 600$ and $1400 \mathrm{~m}$ above sea level and account for the largest potential share of natural forests in Southern Central Europe (Moning and Müller 2008). More than half of Central Europe's surface area consists of mountain areas, which is where most of the existing forests are concentrated (CIPRA 2007).

The presented problem and solution of transforming from artificial to close-to-nature forest is of general importance for the forest management of mountain forests worldwide (Kimmins and Blanco 2011). However, particularly 
in mountainous areas, forests are of great ecological and socio-economic importance in Central and Eastern Europe due to their provision of various ecosystem goods and services (e.g. Ellenberg 1988; Forest Europe 2011; Pretzsch et al. 2015; Mina et al. 2017). The strong topographic gradients and high relative relief strongly increase the propensity for soil loss through erosion (Panagos et al. 2015), as well as gravitational processes such as rockfall, avalanches and snow gliding (Rammer et al. 2015; Leitinger et al. 2018). Furthermore, mountain topography often facilitates heavy local precipitation events and thunderstorms, and human infrastructure is often restricted to flood-prone river valley bottoms. As a consequence, the green infrastructure provided by forests is particularly relevant in mountainous countries. Due to their importance in buffering against the consequences of harsh mountain environments, mountain areas frequently have a substantially higher forest share than low-elevation areas (EEA 2010). They constitute regional hotspots of forest $\mathrm{C}$ storage (Nabuurs et al. 2008) and are estimated to contain $11 \%$ of current global biomass stocks (Erb et al. 2018). In addition to providing regulating services to local communities, mountain forests are thus also relevant for the global climate system.

Spruce, fir and beech have coexisted for thousands of years in mixture without active management or with closeto-nature forestry across this region (Magin 1959; Preuhsler 1979). Interactions between the three species according to the literature seem to be balanced, i.e. the interactions are neither one-sided against or in favour of one of the three species (Pretzsch et al. 2015). For example, in spring conifers may benefit from the neighbourhood of leafless beech by already growing with improved access to water (Goisser et al. 2016; Rötzer et al. 2017). During the common growing season, however, the deeper roots of beech and fir (Lebourgeois et al. 2013) can provide better water supply at the expense of the shallow-rooted spruce. Moreover, in mixed mountain forests spruce and fir are typically higher than beech and can pre-empt the light due to their occupation of the upper canopy layer (Pretzsch et al. 2015). On the other hand, the high morphological plasticity enables beech to more quickly occupy the empty space in case of disturbances (Bayer and Pretzsch 2017).

Both conifers reflect an isohydric strategy (Lyr et al. 1992) and show higher stem and root growth during prolonged time spans under drought than beech (Leuschner 2009; Nikolova et al. 2009). While the hazardous behaviour of the anisohydric beech can lead to tree mortality under the impact of extreme water shortage, the behaviour can be beneficial when water is abundant or moderate drought stress (e.g. Klein 2014). There are more structural and functional traits such as crown plasticity (Jucker et al. 2015; Forrester and Albrecht 2014), rooting depth (Rothe 1997; Schmid and Kazda 2002), litter decomposition (Rothe and Binkley 2001) and browsing pressure (Ammer 1996) that prevent any one of the three species from becoming a permanent winner or loser, and despite their effects changing with climate and growing conditions, the balance between the tree species is maintained.

In terms of stand growth, Hilmers et al. (2019) found that mixed mountain forest ecosystems are rather resilient against disturbances such as acid deposition, climate warming and ozone. As growth reductions in one of the three species were compensated by a growth increase in the others, the stand productivity of mixed mountain forests of spruce, fir and beech in total has hardly changed over the last 30 years. One possible reason for this finding is that the potential damages are rather equally distributed, with late frost and ozone susceptibility of fir and beech (Larsen et al. 1990; Matyssek et al. 2010), the high sensitivity to smoke damage and acid deposition of fir (Elling et al. 2009), the high risk of bark beetle (Wermelinger 2004) and snow and storm damage (Spiecker 2000) of spruce. This temporal, spatial and functional complementarity and risk distribution may contribute to the overyielding of spruce and beech (Pretzsch et al. 2010; Rothe 1997), spruce and fir (Jensen 1983; Pretzsch et al. 2010; Vallet and Pérot 2011; Forrester and Albrecht 2014), and spruce, fir and beech (Pretzsch and Forrester 2017; Mina et al. 2018).

However, mixed mountain forests have often suffered a reduction in species richness. In the German Alps, for instance, spruce has, since medieval times, been heavily promoted as a productive timber species for salt works at sites naturally supporting mixed mountain forests (Seidl et al. 2007). Damage to these secondary pure spruce stands, however, has been steadily increasing in recent decades (e.g. Briner et al. 2013). These forests are particularly vulnerable to summer droughts (Lévesque et al. 2013; Zang et al. 2014), extensive bark beetle outbreaks (Seidl et al. 2014) and pathogens (Porta et al. 2008). All are then further favoured by a warmer and possibly drier climate (e.g. Matulla et al. 2002; Lexer et al. 2002; Pepin et al. 2015). Marini et al. (2012) found that forest disturbance in the European Alps was seven times higher where spruce was planted in sites that were warmer than those within its historical climatic range. However, the importance of whether spruce grows within or outside its native range is decreasing as climate conditions are changing rapidly. Climate change-driven disturbances threaten spruce over virtually its entire range in Europe, and some recent disturbances have, for instance, already reached native subalpine spruce forests close to the timber line in the Alps (Hlásny et al. 2019). In addition, the repeated cultivation of pure spruce stands has a negative effect on soil fertility (Seidl et al. 2007).

To address these problems, alternative management methods are being intensively discussed (Reininger 2000; Spiecker et al. 2004; Löf et al. 2010). A possible option 
to improve the stability and resilience of the stand against abiotic and biotic disturbing factors, as well as to increase productivity, is the transformation of pure spruce stands to site-appropriate mixed mountain forests (Spiecker et al. 2004; Seidl et al. 2011; Pretzsch and Forrester 2017; Hilmers et al. 2019). This transformation has two aspects: (1) a change in the species composition from pure to mixed stands and (2) a change in the stand structure from regular, evenaged stands to more complex, uneven-aged stands.

The advantages of more complex forest stands, for example their higher stability against various disturbances and their superiority regarding many ecosystem services, attract attention (Bauhus et al. 2017; Bravo-Oviedo et al. 2018). Thus, at present there is a tendency towards transformation of age-class monocultures to continuous covered forestry worldwide (Vitkova and Dhubháin 2013). An important argument for fostering more diverse forests, containing both early- and late-successional species, is the insurance hypothesis. This states that diverse ecosystems are better buffered against disturbances (have higher resistance) and recover more quickly (have higher resilience; Jactel et al. 2009). Species diversity can mean risk distribution in view of abiotic and biotic disturbances, stability of growth and permanent protection function (soil erosion, avalanches, flooding). Such mixtures recover considerably faster from disturbances than other ecosystems, due to their elevated response diversity. Moreover, higher stand diversity is positively associated with the supply of many ecosystem services.

The state-of-the-art silvicultural approach in the Alps consists of small, irregular patch cuts for regenerating the forest and maintaining a high level of forest canopy cover in space and time (Cordonnier et al. 2008; Streit et al. 2009). It aims at the supply of regulating services and maintaining a relatively continuous forest cover, while enhancing resistance and resilience to disturbances (Dorren et al. 2004; Brang et al. 2006). However, management is complicated by steep terrain and low accessibility, which requires highly specialised harvesting technologies, (e.g. cable line systems) and results in high management costs (Valente et al. 2014; Jandl et al. 2018). As an alternative, one could adopt a more differentiated strategy, maintaining the existing mixed mountain forests, but transforming pure spruce stands to mixed mountain forests of mainly spruce, fir and beech. Such a strategy is already applied by some forest enterprises (e.g. Bayerische Staatsforsten AöR 2018).

There are hardly any existing practical examples for both maintenance and transformation. Thus, simulations with the forest growth simulator SILVA 2.3 (Pretzsch and Kahn 1996; Pretzsch et al. 2002) served as a supporting tool to assess whether the tested transformation scenarios are successful. Growth models integrate the knowledge about the growth of trees and stands; they can reproduce the growth behaviour of stands with which parameters have been set. After appropriate calibration and validation, however, they are also suitable for reproducing stand development for which there are no sample or illustrative examples yet. For example, simulation models can be used to simulate the consequences of new types of thinning, creation of infrastructures or climate change. The prerequisite for this is that the model internal growth functions reproduce the tree and stand reactions for a broad spectrum of competitive and neighbourhood situations, as well as site conditions, in a biologically plausible way. If this is the case, models can effectively contribute to the development of new management guidelines for forest management in the high mountains (Pretzsch 2019). Besides the state-ofthe-art silvicultural approach in the Alps, however, other silvicultural systems (e.g. gap and strip clear-cut-coupes) were to be compared on multiple criteria.

In addition to topics in numerous studies on the economic aspects of forest transformation (Knoke et al. 2001; Hanewinkel 2001; Knoke and Plusczyk 2001; Knoke et al. 2008; Roessiger et al. 2011; Messerer et al. 2017; Beljan et al. 2018), we investigated the effects of forest transformation on the habitat complex of mixed mountain forests taking a holistic approach. In this sense, the present contribution was devoted to the evaluation of multiple criteria of different forest transformation systems of secondary pure spruce stands, taking into account the criteria of forest growth, economics, carbon sequestration, stand stability and biodiversity. Wood production (forest growth, economics) provides renewable raw materials that are in high demand and wood production jobs are maintained therewith (Sikkema et al. 2011; Hetsch 2008). Carbon sequestration contributes to the mitigation of climate change and can be fostered through both afforestation and forest management (Naudts et al. 2016). Stand stability is fundamental for providing regulating services to society (Moos et al. 2018; Altieri et al. 2018), and biodiversity is likely to play a key role in mediating the relationship between plants and ecosystem processes by influencing the physiology, activity and population dynamics of plants (Weisser and Siemann 2013). The selected criteria are strongly related to the criteria for ecological, economic and social sustainable forest management (MCPFE 1993) which include the care for (1) forest resources, (2) forest ecosystem health and vitality, (3) productive functions, (4) biological diversity, (5) protective functions and (6) socioeconomic functions.

The specific objectives of the contribution were (1) to identify possible paths that can be followed to transform characteristic pure spruce stands into semi-natural mixed forests at equilibrium using different forest management scenarios and to evaluate (2) if the investigated management methods yield stable stands over the long run; and (3) how the different scenarios differ in terms of forest 
growth, economics, carbon sequestration, stand stability and biodiversity.

\section{Materials and methods}

\section{Secondary pure spruce forests}

Starting point for the simulations was formed by a total of 30 different pure spruce stands (Table 1), which were generated by the structural generator, STRUGEN (Pretzsch 1997). Initial data for the simulation and the assumed site productivity were deduced using inventory data of forests in the Bavarian Alps. All the simulated plots covered 2 ha each, at an age of 30 to 40 years, on sites of the 'Oberbayerische Flyschvoralpen' (800-1200 m above sea level, good site conditions). Singlelayered initial stands were characterised by an average basal area of $32.8 \mathrm{~m}^{2} \mathrm{ha}^{-1}$ with an average volume of the remaining stands of $181 \mathrm{~m}^{3} \mathrm{ha}^{-1}$ (Table 1).

\section{Silvicultural goals}

Assuming the help of cable yarding operations, these pure spruce stands were to be transformed to semi-natural mixed mountain forests of beech, spruce and fir at equilibrium. These multi-layered mixed mountain forests should have a mixture of 30-40\% of species other than spruce and, if at equilibrium, an exponentially decreasing stem distribution. In addition, this forests should be uneven-aged, show a high structural diversity as well as an advanced regeneration layer, containing both early- and late-successional species, on as large an area as possible. By regular moderate treatments, the volume of the remaining stand is kept on an optimal level, so that the desired structural diversity and a continuous natural regeneration are obtained. While on rich sites, a volume of the remaining stand of $400-500 \mathrm{~m}^{3} \mathrm{ha}^{-1}$ is aimed at, a volume of the remaining stand of $300-400 \mathrm{~m}^{3} \mathrm{ha}^{-1}$ is targeted on mesic sites. In order to avoid growth reduction, the respective lower value should not be undercut over a longer period of time. Very poor sites were not taken into account, as regular management often takes a back seat in these areas and aspects of forest conservation and protection forest management are in the foreground.

\section{Silvicultural scenarios}

The state-of-the-art silvicultural approach in the Alps (e.g. Bayerische Staatsforsten AöR 2018) is intended to aim at transforming secondary pure spruce stands into semi-natural mixed forests at equilibrium. To sustain the unique functions and services of mixed mountain forests, the natural gap dynamics of mountain forests are emulated by silviculture (e.g. Acevedo et al. 1996; McCarthy 2001; O'Hara 2001; Ciancio et al. 2006). In this context, the most common silvicultural prescription for management is the combined shelterwood and femel-coupe system, which is composed of several stages: spruce stands at the age of 40-60 years are slightly opened up homogeneously over the whole stand area to promote natural regeneration and stability (shelterwood-coupe). Above these patches of forthcoming regeneration, the canopy is opened up continuously or removed completely in one pass (femel-coupe) and missing tree species are planted. In the areas between the regeneration slits, only very cautious interventions (target diameter harvest) take place in order to maintain the volume of the remaining stand between 400 and $500 \mathrm{~m}^{3} \mathrm{ha}^{-1}$ depending on site conditions. With the progressing regeneration of all three species, the regeneration slits are gradually extended by harvesting trees at the edges during the femel-coupe. By removing the overstorey step by step, $40-60$ years after the first harvest, the whole stand area is regenerated as the regeneration patches grow together. Except for the initial shelterwoodcoupe, any remaining thinning operations always only take place on every second cable line. After two operations on the same cable lines, the cable lines are changed. Thus, only half of the area is worked at a time, and the creation and expansion of the regeneration slits take place at different times. This procedure ensures that a heterogeneous vertical structure is created and that the cable lines can also be used over long periods of time. In order to validate the state-of-the-art silvicultural scenarios, the evaluation of multiple criteria was also applied to conventional management methods, such as strip clear-cut and gap-coupe (Mosandl 1984; Table 2).

\section{From silvicultural guidelines to scenario simulation}

All simulations for stand development and timber production were carried out with the single-tree, distance-dependent forest growth simulator, SILVA 2.3 (Pretzsch and Kahn 1996; Pretzsch et al. 2002). Due to the partly stochastic character of SILVA, every simulation run can, despite identical starting conditions and treatment programmes, produce different results. Since the regeneration phase, in particular, provides crucial information for forest transformation concepts, SILVA also includes a regeneration module. Simulations with SILVA were performed as sequences of five-year time steps. In order
Table 1 Key forest growth data of the simulation stands

\begin{tabular}{lllllll}
\hline Species & Age (years) & $\mathrm{N}\left(\mathrm{n} \mathrm{ha}^{-1}\right)$ & $\mathrm{hg}(\mathrm{m})$ & $\mathrm{dg}(\mathrm{cm})$ & Basal area $\left(\mathrm{m}^{2} \mathrm{ha}^{-1}\right)$ & Volume $\left(\mathrm{m}^{3} \mathrm{ha}^{-1}\right)$ \\
\hline Spruce & $30-40$ & $2486 \pm 92$ & $10.7 \pm 0.25$ & $12.2 \pm 0.25$ & $32.8 \pm 1$ & $181.6 \pm 12$ \\
\hline
\end{tabular}

$\mathrm{N}$, stem number per hectare; $\mathrm{dg}$, diameter of mean basal area; hg, mean height corresponding to $\mathrm{dg}$ 


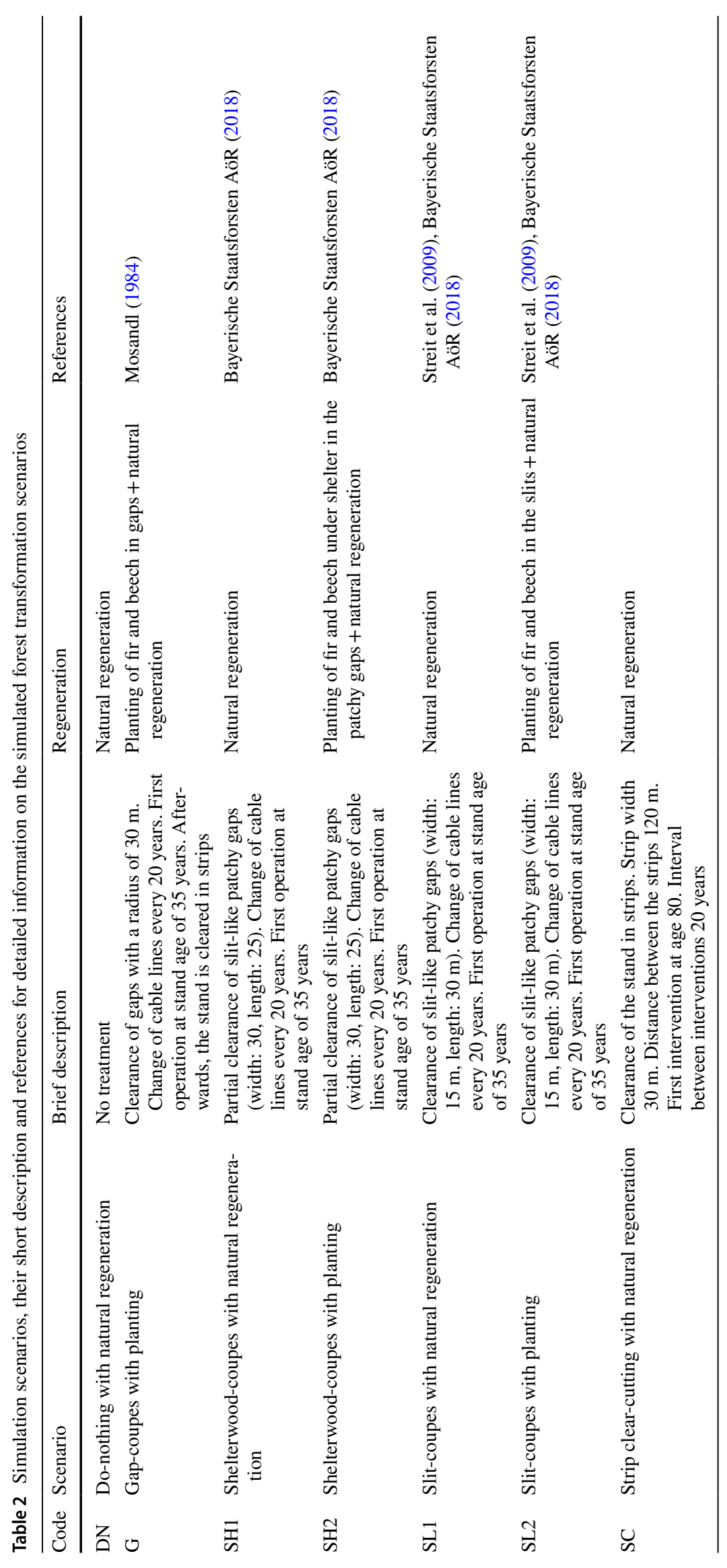


to cover an overall simulation time span of 150 years, we simulated 30 such five-year periods in each run. This means that the development of an entire forest life cycle could be simulated. In addition, the 'silvicultural treatments' (e.g. gap, femel and shelterwood-coupe) and 'creation of infrastructures' (e.g. cable crane and cable lines) modules were supplemented for the present comparison of different silvicultural scenarios. The results of the wood sorting were calculated using the SorSim program (Lemm et al. 2013). Cable lines, femel gaps and planting were created outside the simulator using the data handling features of the R software (R Core Team 2018). The stored carbon quantities in wood products, and the substitution of stored carbon by the energetic use of biomass, were calculated using a harvested wood products (HWP) model from Klein et al. (2013). Comparisons of the results of the different silvicultural scenarios were made using R (R Core Team 2018), specifically employing the dplyr package (Wickham et al. 2018).

\section{Validation of the simulation results}

The simulation results were finally compared with the results from long-term experimental plots. For the validation, data from two sets of long-term experimental plots were used. On the one hand, we used data from 22 mixed mountain forests long-term experimental plots comprising beech, spruce and fir at elevations of between 850 and $1240 \mathrm{~m}$ a.s.l. in the catchment area of the Northern Limestone Alps in Bavaria (Southern Germany). These plots were established in order to investigate the influence of different silvicultural treatments (femel-shelterwood-coup) on the regeneration dynamics and volume increment and were established in the 1970s (Pretzsch et al. 2015). Moreover, we have compared our results with data from 14 long-term experimental pure spruce plots on high-performance sites in southern Bavaria (Röhle 1995).

\section{Evaluation criteria}

To engage in differentiated discussions on all transformation scenarios (Table 2) five criteria (forest growth, economics, carbon sequestration, stand stability and biodiversity) were defined. The results of each silvicultural scenario and criterion were displayed scaled (best: 1, worst: 0; Koschke et al. 2012; Knoke et al. 2014). Each criterion was, in turn, made up of different factors (see Table 3 ). The efficiency of each scenario was quantified by summing the score of each of the studied criteria. To provide a measure of stability between the categories, the standard deviation (SD) for each forest transformation scenario was also determined.

\section{Forest growth}

The criterion forest growth consisted of the factor's total productivity, mortality over the entire simulation period and the standard deviation of tree heights as a proxy for a shelter in the event of a disturbance. If the overstorey is lost to disturbances, the understory can immediately utilise the increasingly available resources such as light, water and nutrients and take over important forest functions. In order to include the temporal component, the time since simulation start was classified into five classes $(25 \pm 10,50 \pm 10$, $75 \pm 10,100 \pm 10$ and $125 \pm 10$ years), and averages of each class were obtained. Each of the five values was included in the evaluation without weighting.

\section{Economics}

The harvested trees were graded after each simulation period with the help of SorSim (Lemm et al. 2013) without the dead wood fraction. The revenues were calculated using averaged timber prices provided by the Bavarian State Institute of Forestry (LWF) for 2010-2015. Harvesting costs were calculated at $48 € \mathrm{~m}^{-3}$, planting costs at $6400 € \mathrm{ha}^{-1}$ for beech, $1600 € \mathrm{ha}^{-1}$ for spruce and $2700 € \mathrm{ha}^{-1}$ for fir. The net present value (NPV) was calculated using three different discount rates: $1 \%, 2 \%$ and $3 \%$. The presented results included the financial value of the standing timber at the end of the simulation period.

\section{Carbon sequestration}

In order to calculate the stored in situ carbon quantities of the simulation results, both the above-ground biomass, using species-specific biomass formulae (Pretzsch et al. 2014), as

Table 3 Overview of the categories defined for the comparison of the different forest transformation scenarios and their factors

\begin{tabular}{|c|c|c|c|c|}
\hline Forest growth & $\begin{array}{l}\text { Economics (net present } \\
\text { value) }(\%)\end{array}$ & Carbon sequestration & Stability & $\begin{array}{l}\text { Biodiversity (number of } \\
\text { species) }\end{array}$ \\
\hline $\begin{array}{l}\text { Total productivity } \\
\text { Mortality } \\
\text { Standard deviation of tree } \\
\text { heights }\end{array}$ & $\begin{array}{l}1 \\
2 \\
3\end{array}$ & $\begin{array}{l}\text { In situ }+ \text { ex situ in wood } \\
\text { products }+ \text { substitutions of } \\
\text { fossil fuels }\end{array}$ & $\begin{array}{l}\text { Survival probability of } \\
\text { spruce * potential dam- } \\
\text { aged timber } \\
\text { Spruce proportion in the } \\
\text { last simulation period }\end{array}$ & $\begin{array}{l}\text { Flora } \\
\text { Fauna } \\
\text { Fungi }\end{array}$ \\
\hline
\end{tabular}

Each factor was included in the evaluation of the respective category without weighting 
well as the underground biomass, with a root factor (root/ shoot) according to Offenthaler and Hochbichler (2006), were estimated. The ex situ carbon content in wood products and the substitution quantities resulting from bioenergy use (wood combustion) were calculated using a harvested wood products (HWP) model from Klein et al. (2013). In presenting the $\mathrm{C}$ sequestration potential of forest management on a per hectare basis, we used the levelisation approach, where the periodic $\mathrm{C}$ flows were summed up and discounted with an assumed social interest rate of $2 \%$ (e.g. Hoen and Solberg 1994).

\section{Biodiversity}

The number of species of (1) flora, (2) fauna and (3) fungi were selected as indicators for a non-wood forest function. In order to determine the number of species of flora, fauna and fungi, each of the 30 stands was divided into $1000-\mathrm{m}^{2}$ grids. According to Zenner et al. (2016), each raster was then assigned to one of nine forest successional stages (gap, regeneration, establishment, early optimum, mid-optimum, late optimum, plenter, terminal and decay). Finally, based on the results of Hilmers et al. (2018), the number of species of flora (higher plants, lichen and mosses), fauna (phytophagous and pollinating arthropods, vertebrates and invertebrates feeding on animal tissue, species feeding on dead tissue and species depending on dead wood during their life cycle) and fungi was able to be assigned to the individual forest successional stages. The species numbers of the entire 2-ha plots consisted of the average of all $1000 \mathrm{~m}^{2}$ large squares. Standard deviations were also calculated again using the average of each of the five classes since simualtion start (see above).

\section{Stability}

The calculations of the stability of the stand against natural disturbances were calculated on the basis of a model developed by Roessiger et al. (2013). In a mixed stand, the survival probability of the spruce was calculated by means of a Weibull function (Weibull 1951) depending on the percentage of spruce and age. The probabilities of beech and fir survival were assumed to be independent of the percentage of spruce (Roessiger et al. 2013). Using the five classes since simulation start (see above), the survival probabilities were calculated at different simulation points in time. These survival probabilities were then multiplied by the potential amount of damaged wood volume (all spruce trees higher than $66 \%$ of the mean height of the 100 thickest spruce trees). They were then included in the valuation as separate factors without weighting. Assuming that stable stands at the end of the simulation could either appear due to the young age of the spruce, or due to a low proportion of spruce, the share of spruce of the total stand in the last simulation period was used as an additional factor. Since those stands with a high proportion of spruce and young age will become unstable again in the future, those stands with a lower proportion of spruce were rated as better.

\section{Results}

Apart from the strip clear-cut and the do-nothing scenario, all the methods were successful for transformation into semi-natural mixed forests at equilibrium. Although natural regeneration of beech and fir was always present in the strip clear-cut scenario, spruce dominated the advanced development phases of the stands. In the do-nothing scenario, no or very little natural regeneration occurred. Differences between the shelterwood, slit and gap scenarios are shown in terms of their specific criteria.

\section{Validation of the simulation results}

Figure 1 shows the periodic annual increment versus the volume of the remaining stand in each simulation period. The results of the do-nothing scenario showed that longterm experimental plots made of pure spruce showed higher growth rates at the same volumes of the remaining stand

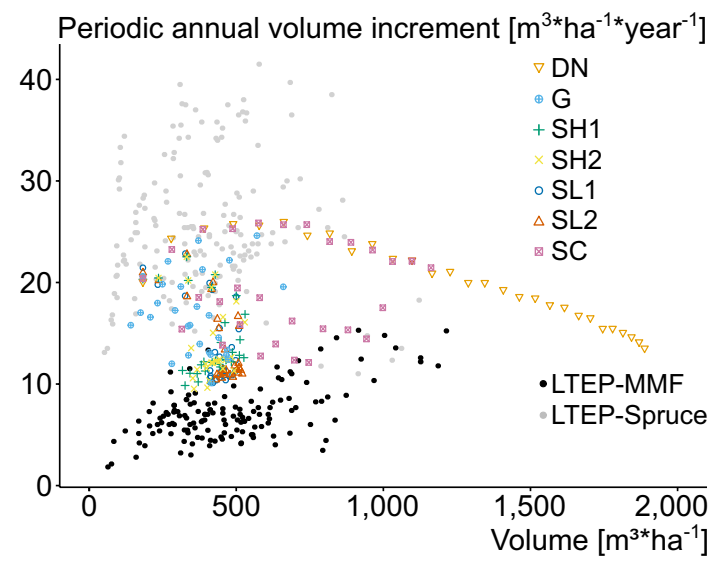

Fig. 1 Relationship between stand periodic annual volume increment and volume of the remaining stand. Black dots show the results from long-term experimental plots consisting of pure spruce (LTEPSpruce); grey dots show the results from long-term experimental plots consisting of spruce, fir and beech (LTEP-MMF). Other symbols show the simulation results of various forest transformation scenarios. DN, do-nothing scenario; G, gap-coupes with planting of beech and fir; SH1, shelterwood-coupes with natural regeneration; $\mathrm{SH} 2$, shelterwood-coupes with planting of fir and beech; SL1, slitcoupes with natural regeneration; SL2, slit-coupes with planting of fir and beech; SC, strip clear-cutting with natural regeneration. See Table 2 for a detailed description of the different scenarios. For interpretation of the references to colour in this figure legend, the reader is referred to the web version of this article 
than experimental plots from the mixed mountain forest zone (beech, spruce and fir). The results from the simulations for all scenarios were lying between the results of the long-term experimental plots.

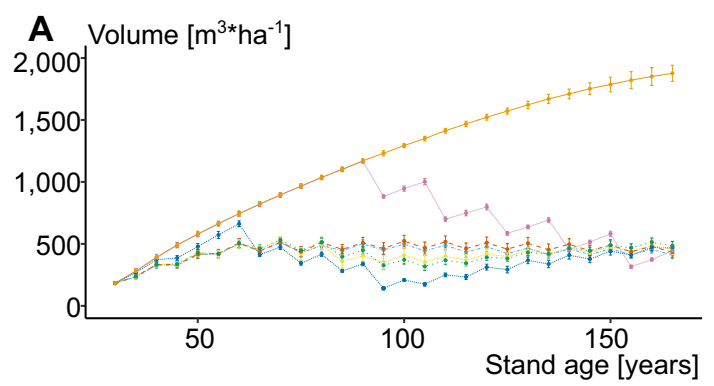

B Periodic annual volume increment $\left[\mathrm{m}^{3 *} \mathrm{ha}^{-1 *}\right.$ year $\left.^{-1}\right]$

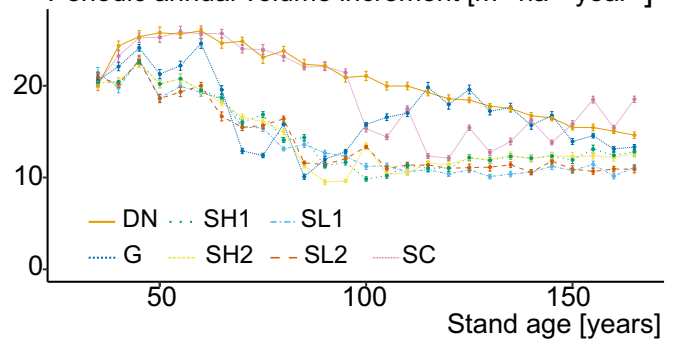

Fig. 2 Volume of the remaining stand in $\mathrm{m}^{3} \mathrm{ha}^{-1}$ (a) and stand periodic annual volume increment in $\mathrm{m}^{3} \mathrm{ha}^{-1}$ year $^{-1}$ (b) with standard errors, resulting from different tree growth between 30 simulations, above stand age of all the simulated transformation scenarios. DN, do-nothing scenario; G, gap-coupes with planting of beech and fir; $\mathrm{SH} 1$, shelterwood-coupes with natural regeneration; $\mathrm{SH} 2$, shelterwood-coupes with planting of fir and beech; SL1, slit-coupes with natural regeneration; SL2, slit-coupes with planting of fir and beech; SC, strip clear-cutting with natural regeneration. See Table 2 for a detailed description of the different scenarios. For interpretation of the references to colour in this figure legend, the reader is referred to the web version of this article

\section{Forest growth}

The stand periodic annual volume increment (PAIV) of the slit and shelterwood scenarios stabilised from a stand age of around 80 years to a value of approx. $10 \mathrm{~m}^{3} \mathrm{ha}^{-1}$ year $^{-1}$ and formed a steady state until the end of the simulation (Fig. 2). Volume of the remaining stand in the slit and shelterwood scenarios quickly leveled out between 400 and $500 \mathrm{~m}^{3} \mathrm{ha}^{-1}$. Figure 3 shows how the slit scenario approaches a possible steady-state curve in the simulation run after 150 years. It is striking how the 'gap' in the diameter frequency distribution between 20 and $30 \mathrm{~cm}$, still visible after 110 years of simulation, was filled after 130 years of simulation.

However, due to higher stand densities, the PAIV of the do-nothing scenario was higher than for all other scenarios over the entire simulation period (Fig. 2). In the case of standing volume and PAIV, the strip clear-cut scenario was similar to that of the do-nothing scenario up to the time of the first treatment. The gap scenario also showed the greatest fluctuations in terms of PAIV, similar to the standing volume.

\section{Economics}

In terms of economics, the results were similar for most management scenarios. Just the results of the do-nothing and the strip clear-cut scenario differed from the others (Figs. 4, S1). The do-nothing scenario showed, due to the potential liquidation value of the portfolio at the end of the simulation period, comparable net present values only in the calculation of the net present values with a $1 \%$ discount rate. As the discount rate increased, the net present value droped sharply and was significantly smaller than in the other scenarios.
Fig. 3 Stem distribution (N/ ha for DBH-classes) of the slitcoupe scenario with planting of fir and beech after 100, 110, 120,130 and 150 years of simulation. The curve corresponds to a steady-state condition for uneven-aged stands of spruce, which could be reached in the long run (Prodan 1944). Note that the number of trees per hectare and DBH-classes was log transformed
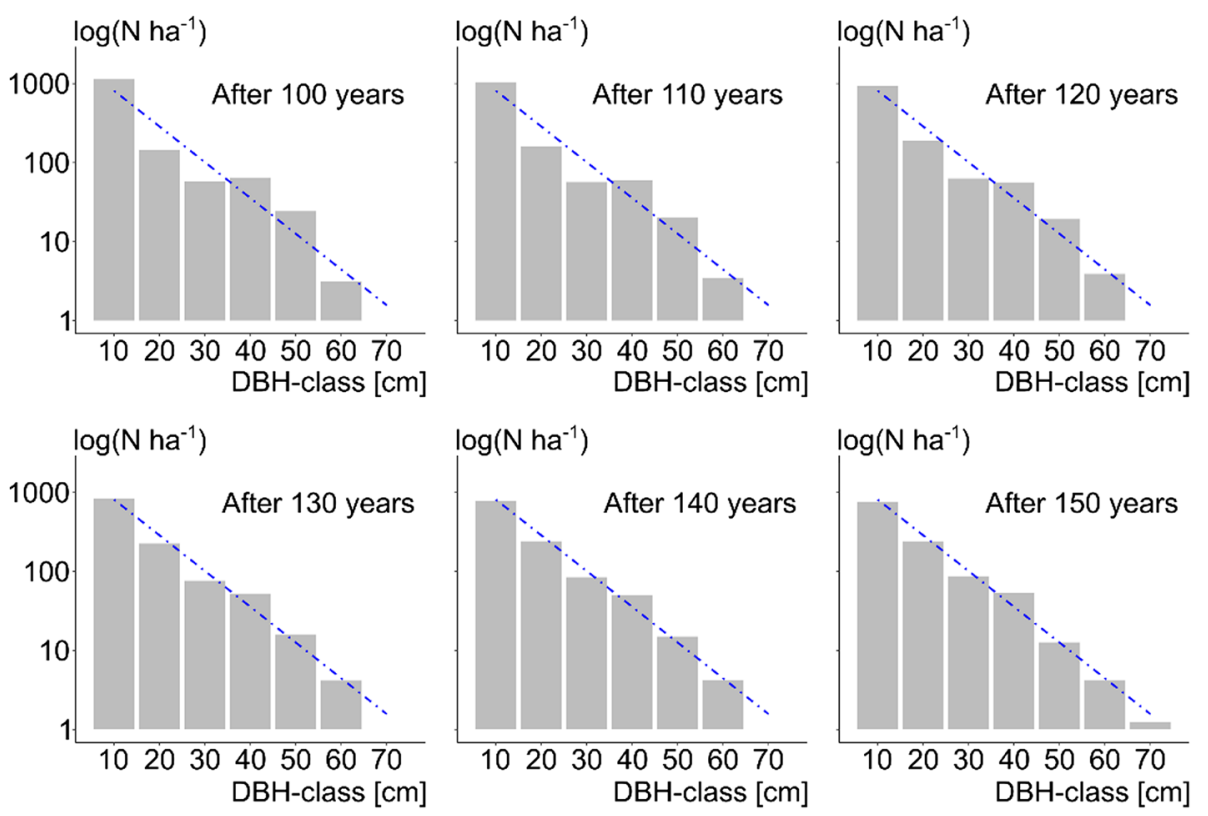

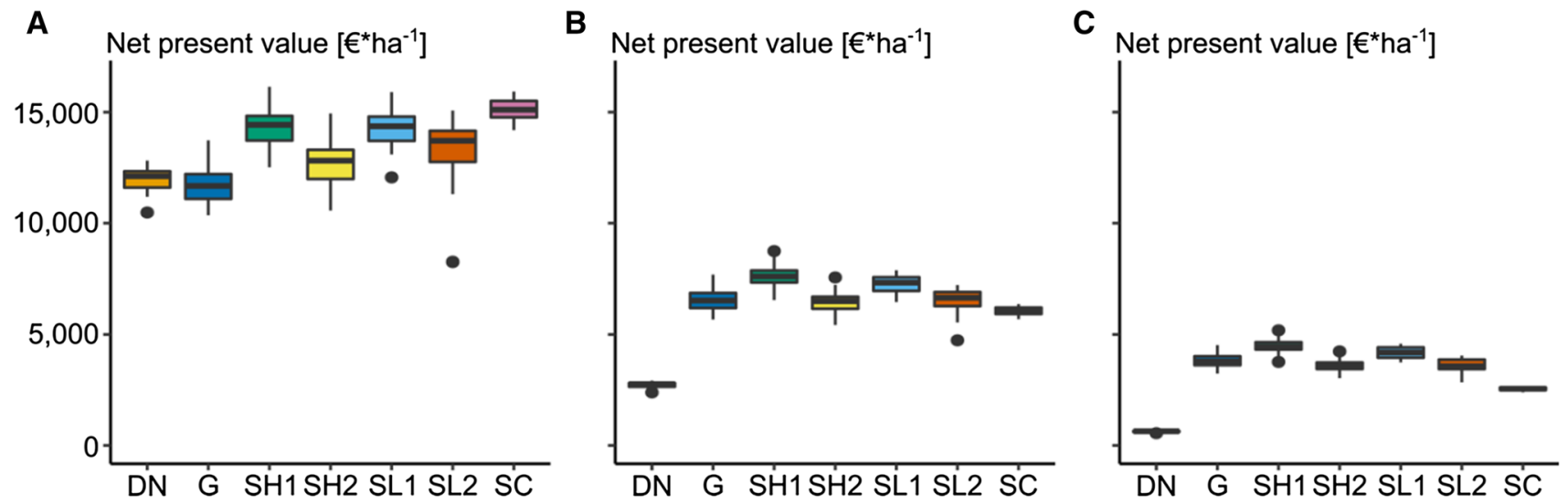

Fig. 4 Boxplots of the net present values of the different transformation scenarios. The net present value is calculated using three different interest rates: $1 \%(\mathbf{a}), 2 \%(\mathbf{b})$ and $3 \%(\mathbf{c})$. The presented results include the potential liquidation value of the portfolio at the end of the simulation period. DN, do-nothing scenario; G, gap-coupes with planting of beech and fir; SH1, shelterwood-coupes with natu-

Table 4 Mean $\mathrm{C}$ sequestration $\left(\mathrm{tC} \mathrm{ha}^{-1}\right.$ ) according to the levelisation approach in the different scenarios over 150 years

\begin{tabular}{lrccc}
\hline Scenario & In-situ & Wood products & Substitution & Total \\
\hline DN & 171.5 & 0.0 & 0.0 & 171.5 \\
G & 47.5 & 30.9 & 321.5 & 399.9 \\
SH1 & 47.8 & 27.6 & 258.9 & 334.4 \\
SH2 & 48.4 & 26.8 & 249.1 & 324.3 \\
SL1 & 49.1 & 26.7 & 262.1 & 337.9 \\
SSL2 & 52.4 & 25.3 & 247.7 & 325.4 \\
SC & 110.9 & 15.8 & 275.3 & 401.9 \\
\hline
\end{tabular}

See Table 2 for abbreviations and a detailed description of the different scenarios

A very similar pattern can be observed in the strip clearcut scenario. Even if it was still the best variant in the calculation with a discount rate of $1 \%$, it fell behind the slit, shelterwood and gap variants in the calculation with higher discount rates. The slit, shelterwood and gap variants only differed in the planting costs of beech and fir and otherwise showed very similar results. However, the planting costs had a very strong impact on the net present values.

\section{Carbon sequestration}

Table 4 shows the mean carbon sequestration of the seven transformation scenarios, as well as the in situ storage, the carbon storage in wood products and the substitution of fossil fuels. The do-nothing scenario showed the highest in situ storage. Due to the lack of intervention, however, no carbon was stored in wood products or achieved by substituting fossil fuels. Overall, the do-nothing variant was, therefore, the ral regeneration; $\mathrm{SH} 2$, shelterwood-coupes with planting of fir and beech; SL1, slit-coupes with natural regeneration; SL2, slit-coupes with planting of fir and beech; SC, strip clear-cutting with natural regeneration. See Table 2 for a detailed description of the different scenarios

one with the lowest carbon sequestrate values. Highest values were achieved by the strip clear-cut and gap scenarios. While the strip clear-cut scenario showed high in situ carbon storage values, the gap variant had higher values in the areas of wood products and substitution of fossil fuels. The shelterwood and slit scenarios showed similar values with slightly higher values in the scenarios with natural regeneration. Overall, our results showed that the substitutions of fossil fuels were the most important factor to consider when looking at total carbon sequestration.

\section{Stability}

In terms of stability, we found the highest potential damages of spruce caused by disturbances in the do-nothing scenario (Fig. 5). Survival probabilities decreased with age. As we found the highest values of volume of the remaining stand, the potential damaged wood volume was also the highest for this scenario. For the other scenarios, the survival probabilities decreased for the first 100 years of simulations and then after increased. The proportion of spruce was $100 \%$ in the do-nothing and the strip clear-cut scenario at the end of the simulation runs. In case of slit and shelterwood, the proportions of spruce at the end of the simulations were higher in the scenarios with natural regeneration, than in the ones with plantings of beech and fir. Although beech and fir were planted in the gap scenario, the proportion of spruce at the end was still high (75\%).

\section{Biodiversity}

For all three kingdoms (flora, fauna and fungi), considerable changes in the potential number of species were observed 


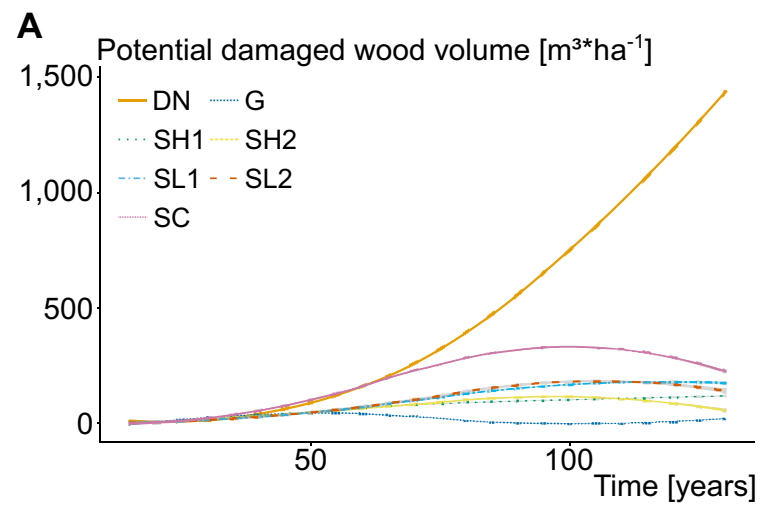

Fig. 5 Relationship between the potential damaged wood volume and the time since simulation start of all simulated scenarios (a) and the proportion of spruce in the last simulation period (b). Lines were generated by fitting a loess curve. DN, do-nothing scenario; G, gap-coupes with planting of beech and fir; SH1, shelterwood-coupes with natural regeneration; $\mathrm{SH} 2$, shelterwood-coupes with planting of

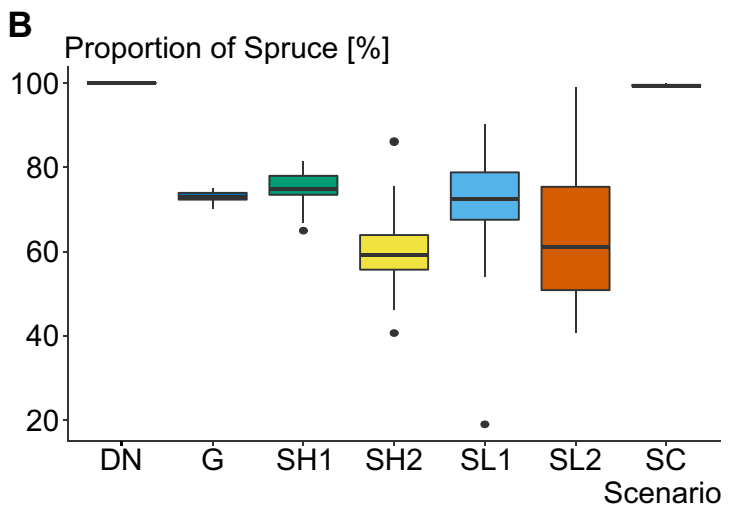

fir and beech; SL1, slit-coupes with natural regeneration; SL2, slitcoupes with planting of fir and beech; SC, strip clear-cutting with natural regeneration. See Table 2 for a detailed description of the different scenarios. For interpretation of the references to colour in this figure legend, the reader is referred to the web version of this article

pattern along forest succession. We found an increasing number of species of fungi in the do-nothing and strip clear-cut scenarios peaking at 50 years of simulation (Fig. 6c). While we found just a slight decrease in the number of species in the do-nothing scenario afterwards, the number of species decreased drastically in the strip clear-cut scenario due to starting silvicultural treatments. In the slit and shelterwood scenarios, the number of species was lower during the first 70 years of simulation. However, as canopy density increased the number of fungi species was highest in these scenarios during the last 80 years of simulation. A different pattern was found in the gap-coupes scenario. In this scenario, the number of species was lowest during the first 70 years of simulation, increased afterwards with a peak at 130 years of simulation and slightly decreased at the end of the simulation runs.

\section{Evaluation with multiple criteria}

to the strong silvicultural treatment towards the end of the simulation, the number of species increased again in this scenario.

As consumers depend on the primary producers, the number of species in the fauna kingdom showed very similar trends (Fig. 6b). The number of species rose sharply for a period in the slit, gap and shelterwood scenarios (open canopies), decreased afterwards and were constant at the end of the simulation runs. Again the number of species increased at the end of the simulation runs in the gap scenario. The do-nothing scenario showed a high number of species after 100 years of simulation.

Contrasting to the kingdoms of flora and fauna, the number of fungi species are following a bell-shaped
Figure 7 shows the results of the overall evaluation with regard to the individual scenarios concepts. The do-nothing scenario showed the best biodiversity performance and ranked last for the other four criteria. The slit scenario with natural regeneration, slit with planting and the gap scenario showed balanced results in all categories. The results of the shelterwood scenario with natural regeneration, shelterwood with planting and the strip clear-cut scenario showed divergent results between the criteria. In order to illustrate the divergence of all the criteria within a silvicultural scenario, the standard deviation of each scenario between the categories was calculated (Fig. 8). This 

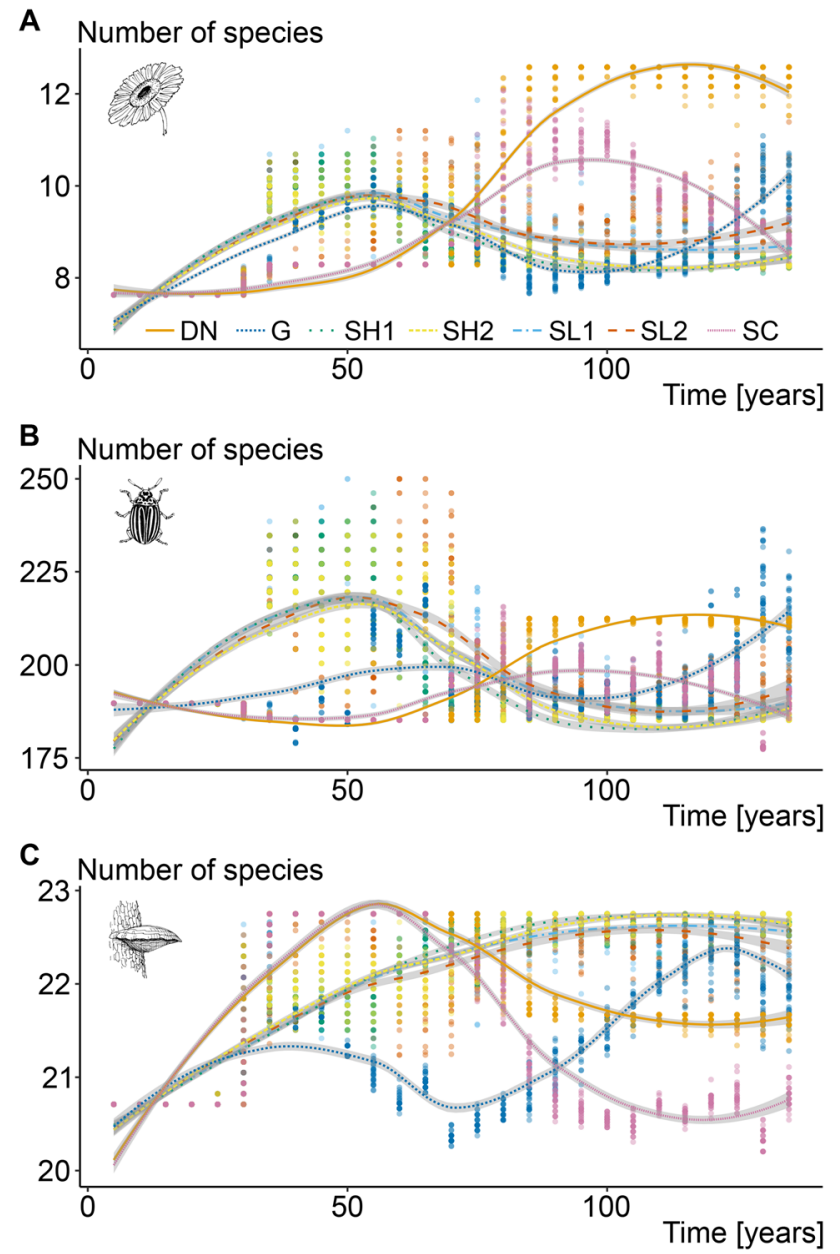

Fig. 6 Trends in the number of species of flora (a), fauna (b) and fungi (c) for time since simulation start of all the simulated scenarios. Lines were generated by fitting a loess curve. Grey areas represent the $95 \%$ confidence interval. DN, do-nothing scenario; G, gap-coupes with planting of beech and fir; SH1, shelterwood-coupes with natural regeneration; $\mathrm{SH} 2$, shelterwood-coupes with planting of fir and beech; SL1, slit-coupes with natural regeneration; SL2, slit-coupes with planting of fir and beech; SC, strip clear-cutting with natural regeneration. See Table 2 for a detailed description of the different scenarios. For interpretation of the references to colour in this figure legend, the reader is referred to the web version of this article

approach enables a direct comparison of the individual silvicultural scenarios based on the total score. Scenarios, such as the slit scenarios with a high total score and small standard deviations between the scores, can be described as stable. The shelterwood scenarios show a relatively high total score, but at the expense of a higher standard deviation.

\section{Discussion}

It was shown that it might be possible to transform secondary pure spruce stands to stable mixed mountain forests with five of the seven scenarios (H1). It is also these five scenarios (gap, shelterwood, slit) which are expected to maintain these structures in the long term with regular forest interventions (H2). The evaluation of multiple criteria allows the seven scenarios to be divided into three groups. The do-nothing scenario only achieved the highest score in the category of biodiversity. The shelterwood and strip clear-cut scenarios showed highly divergent scores, while the slit and gap scenarios achieved high scores in all categories (H3).

While the management scenarios studied here mimic current management recommendations (Mosandl 1984; Streit et al. 2009; Bayerische Staatsforsten AöR 2018) in a highly realistic manner, it was applied uniformly across all the simulation runs. This approach disregards the potential adaptive measures of managers (Yousefpour et al. 2017), which are increasingly likely as climate change impacts worsen (Blennow et al. 2012; Seidl et al. 2016). Furthermore, it is unrealistic to presume constant site and climatic conditions for the next 150 years, as chosen in the present investigation. The simulation of a site-condition drift is, in principle, possible with the used growth model by changing the height or diameter-growth potential over time. For our simulation runs, where the central goal was the comparison of distinctly different treatment strategies, we assumed steady-state climatic and site conditions (Hanewinkel and Pretzsch 2000).

Despite these limitations, one of the backbones of this study is the reliability of the model SILVA in terms of providing the realistic quantitative results in terms of tree and stand growth. The model is used for applications in practice since the late 1990s, and the current version has been quantitatively calibrated with about 350,000 single-tree growth observations from long-term research plots (Pretzsch 2009, p. 519). Mixed mountain forests and pure spruce stands in Bavaria are particularly well represented in this data set. Thus, this study applied the model in a core area of its validity, which became also evident in the presented validation runs. The evaluation criterion forest growth was therefore directly covered by this validity. The other criteria (economics, carbon sequestration, biodiversity, stability), in contrast, were not primary simulation output variables, and they rather result from secondary calculations made on the former. However, the development of the standing stock and growth and the achievement of a long-term steady state play a crucial role, and most other criteria depend on this steadystate structure, volume and growth (Forest Europe 2011; MCPFE 1993; Dieler et al. 2017). All the methods applied and associated assumptions are documented and verified in published research works (see corresponding parts of the 


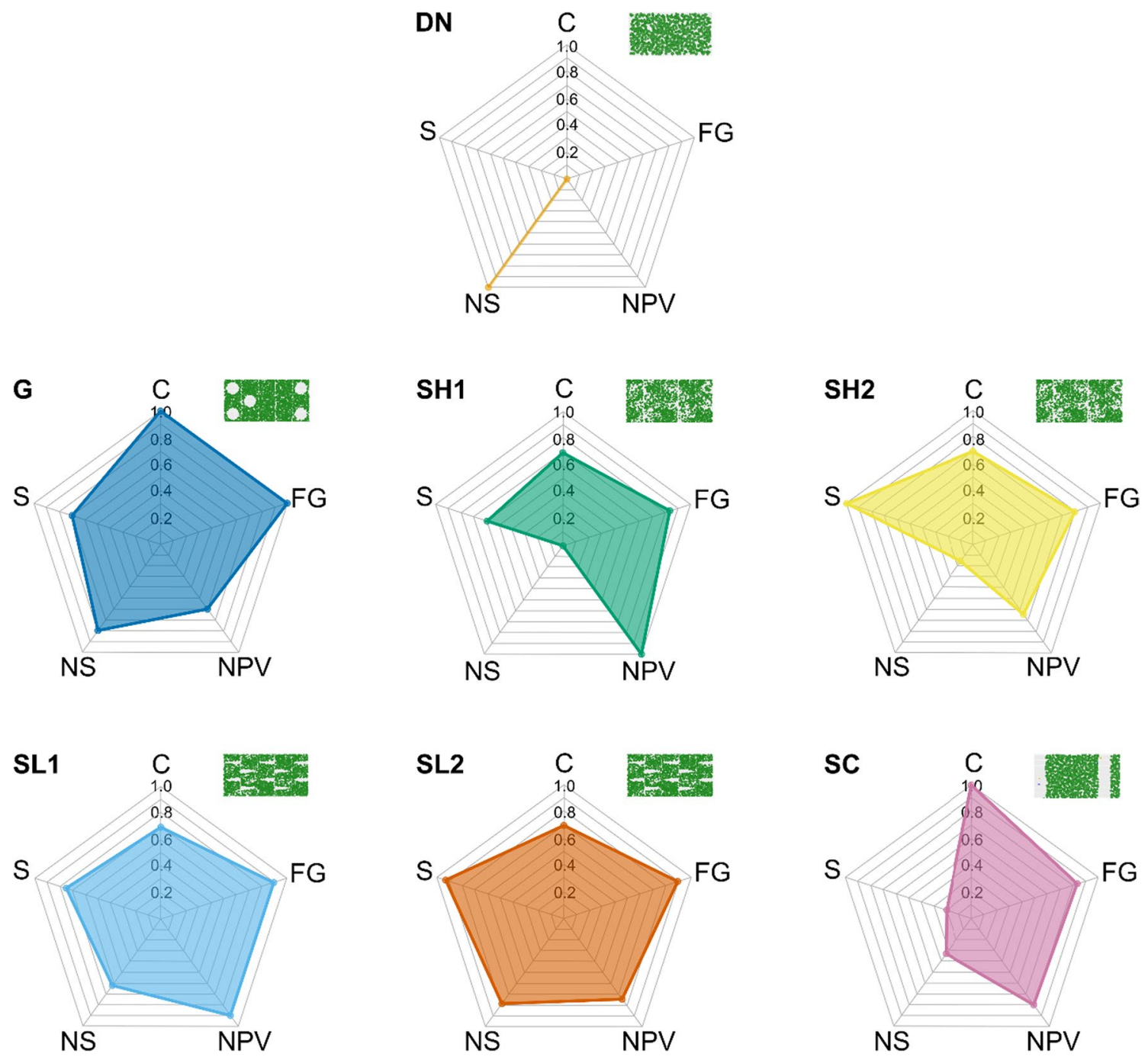

Fig. 7 Radar chart of the evaluation of multiple criteria. FG, forest growth; NPV, net present value; C, carbon sequestration; S, stability; NS, number of species. The scaled results of the respective factors of each criterion are shown (see Table 3 for explanation). The results were scaled between 0 and 1 . The results evaluated with 1 represent the best scenario in comparison with the other scenarios. Categories rated 0 show the worst scenario. DN, do-nothing scenario; G,

methods section). So, we feel, our simulation and evaluation methodology — with a valid growth and yield model at its fundament—can be meaningfully applied given the goals of this study.

\section{Forest transformation}

The newly introduced species (beech and fir) can be established by planting or natural regeneration after artificial disturbances such as shelterwood, slit or gap-coupes. In their study on the transformation of even-aged to uneven-aged stands of spruce, Hanewinkel and Pretzsch (2000) showed that a transformation is strongly dependent on the gap size. gap-coupes with planting of beech and fir; SH1, shelterwood-coupes with natural regeneration; $\mathrm{SH} 2$, shelterwood-coupes with planting of fir and beech; SL1, slit-coupes with natural regeneration; SL2, slitcoupes with planting of fir and beech; SC, strip clear-cutting with natural regeneration. See Table 2 for a detailed description of the different scenarios

They showed that regeneration can only be established from gap sizes larger than $40 \mathrm{~m}$ in diameter. However, this study only includes the regeneration of spruce. Our study demonstrates that smaller gap sizes are sufficient if shade tolerant species are involved in the transformation process by planting or from natural regeneration if potential mast trees are located nearby. The smaller interventions also have less impact on the periodic annual volume increment at the stand level. This is in line with Brunner et al. (2006) who demonstrated, based on silvicultural scenario modelling, a transformation of spruce stands by under-planting with beech in a gradually opened stand of spruce. 


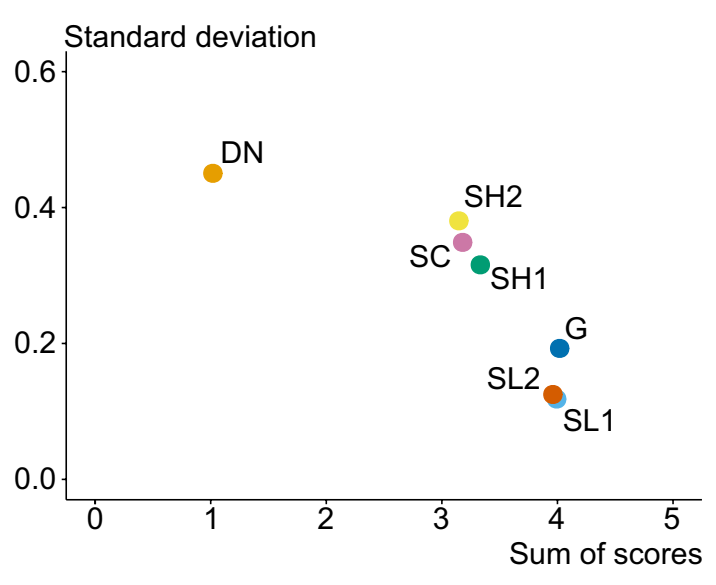

Fig. 8 Standard deviation of the scores from the five criteria (forest growth, economics, carbon sequestration, (stand) stability and biodiversity) over the sum of the scores. DN, do-nothing scenario; G, gap-coupes with planting of beech and fir; SH1, shelterwood-coupes with natural regeneration; $\mathrm{SH} 2$, shelterwood-coupes with planting of fir and beech; SL1, slit-coupes with natural regeneration; SL2, slitcoupes with planting of fir and beech; SC, strip clear-cutting with natural regeneration. See Table 2 for a detailed description of the different scenarios and Table 3 for an overview of the five criteria

In the strip clear-cut scenario, after the removal of all the trees from the strip, natural regeneration of beech and fir started (if potential mast trees are located nearby). However, beech and fir were outcompeted by spruce later on. This may be avoided by earlier planting or groupwise separation of the three species, for example, through pre-commercial thinning (Brunner et al. 2006). Regulation of the mixture could be accomplished in SILVA only by thinning crop trees at a very early age. However, in the long run, the small-scale interventions of the slit-coupe scenarios might better support asynchronous forest dynamics than the other scenarios and thus support the forest's inherent adaptive mechanisms (Morin et al. 2014). In the do-nothing scenario, spruce remained dominant until the end of the simulation and the regeneration of fir and beech appeared only slowly. Suggestions by e.g. Drever et al. (2006) that unmanaged development might enable natural processes to restore the original species composition of the forests cannot be supported by our study, at least not in the time span of the simulation period. The slow rate of tree species change agrees with Schelhaas et al. (2015), who suggested that European forests are very inert and that altering their species composition requires a long time. The simulation results of Hlásny et al. (2017) in the Goat Backs mountain area of Slovakia also confirm these results. However, larger natural disturbances are to be expected in mountainous forests (Bircher et al. 2016), and the partial accumulation of the natural regeneration of non-spruce species is realistic (Buma and Wessman 2013). In all presented scenarios, climate change and disturbance-mediated support to tree species diversity should be considered as an opportunity for forest adaptation efforts in spruce-dominated stands. Indeed, adverse effects, such as productivity losses or bark beetle outbreaks, must not be marginalised (Jönsson et al. 2007; Fleischer et al. 2016; Hlásny et al. 2017).

The lower stand periodic annual volume increment of long-term experimental plots has to be put into perspective to the extent that the proportion of spruce in the simulation plots was higher, and disturbing events, such as wind and bark beetle infestation, cannot be adequately represented by SILVA. As damage was not modelled in our scenarios, the standing volume of the remaining stand in the do-nothing scenario reached values of almost $2000 \mathrm{~m}^{3} \mathrm{ha}^{-1}$ only occasionally found on experimental plots. The comparative results from untreated long-term experimental plots with pure spruce show maximum volumes of the remaining stand of approx. $1600 \mathrm{~m}^{3} \mathrm{ha}^{-1}$ (Röhle 1995). We accepted this bias in the results as all the scenarios were flawed in the same way. We were interested in the relative differences and ranking of the scenarios, rather than in their absolute performance.

In order to transform the destabilised pure spruce forests into stable mixed mountain forests on a large scale, methods should be found to reduce the high harvest costs (Valente et al. 2014; Jandl et al. 2018). For example, Valente et al. (2011) demonstrate that a whole-tree system employed in alpine conditions showed lower costs and emissions and therefore offered greater economic and environmental benefits than the traditional shortwood system. Furthermore, the same authors showed that cable yarding seems to be very efficient in terms of having a minimal impact on residual stand and soil which seems particularly important against the background of already destabilised forests.

\section{Long-term safeguarding of forest transformation}

Although the slit and shelterwood scenarios reached steadystate conditions at the last 50 years of the simulation runs, these structures can only be artificially maintained in their characteristic structures by continuous removal in the upper and middle layers. Without silvicultural interventions over a longer period of time, the upper and middle layers may become so dense that the regeneration layer no longer receives enough light, precipitates and the balanced age structure is lost (Pretzsch 2019). Anyway, as long as there are continuous silvicultural interventions, tree species compositions will remain stable due to the slit and shelterwood scenarios and will ensure the desired forest redevelopment in the long term. The gap scenario also suggests that the transformation will be successful in the long term. Although this scenario is, due to the higher amounts of harvested wood, less stable in terms of stand periodic annual 
volume increment over the entire simulation period, this scenario achieves a higher tree species mixture and an unevenaged structure at the end of the simulation runs. In terms of productivity, these mixed uneven-aged stands have the advantage of being more productive compared to neighbouring pure stands (Pretzsch et al. 2015) on the one hand, and, on the other hand, that a potential reduction in the volume increment of one species can be compensated for by higher volume increments of another species (Hilmers et al. 2019).

\section{Evaluation of multiple criteria}

The evaluation of multiple criteria allowed to highlight three basic patterns: The shelterwood and strip clear-cut scenarios showed highly divergent scores, while the slit and gap scenarios achieved high scores in all categories. The do-nothing scenario only achieved the highest score in the category of biodiversity. However, as unmanaged forests are increasingly valued for their benefits in the context of biodiversity conservation (Paillet et al. 2010), an increasing share in the landscape will not necessarily lead to a reduction in important regulating ecosystem services. For example, Seidl et al. (2019) showed that, in a mountain forest landscape, the regulation of both climate and erosion was higher in unmanaged systems, compared to systems implementing current management recommendations (see also Irauschek et al. 2017; Mina et al. 2017; Langner et al. 2017). It is important to note, however, that many rural mountain communities not only depend on regulating ecosystem services, but also generate a substantial part of their income and livelihood from managing natural resources (Häyhä et al. 2015). Not managing forests might thus negatively affect rural communities and result in the loss of other important ecosystem services, such as the supply of timber and biomass for bioenergy.

Although the evaluation of multiple criteria presented here is innovative for a holistic view of silvicultural concepts, the entire forest complex should not be reduced to the criteria described here. Furthermore, the considered indicators are only proxies for the respective services and differ with regard to how closely they resemble the relevant underlying processes. However, based on the available results, the determinant effects of the different silvicultural concepts could be made visible, even for those who have not yet been able to draw on empirical studies or practical experience because of the new concepts. It was the aim of this study to develop and evaluate a set of technically feasible management options for the transformation to semi-natural mountain forests; the choice of the optimum or best scenario also depends on economic, social, legal and eco-political factors not covered by this study.

\section{Significance for forest transformation worldwide}

Forestry has been changing throughout its history in response to the changing needs of human populations and changing supplies of forest resources and values to satisfy these needs (Kimmins and Blanco 2011). Worldwide, there is a multitude of forests which have been destabilised during history. For example, the forests in Bangladesh or the temperate rainforests in Canada and the USA face similar challenges to the destabilised forests in the Alps of Europe resulting from the former salt works supply. They are to be transformed to sustainable, stable but managed systems. Our results show that there are several equivalent trajectories to achieve these goals. Thus, the risk of failure if one does not strictly follow a sophisticated guideline is low. There is little reason, therefore, why transformation of destabilised forest should not be attempted in order to suffer fewer human casualties and economic damage in the future, in many regions of the world.

\section{Conclusion}

Silvicultural scenario comparisons quantify the long-lasting impact of management decisions on the stand and landscape (Niedertscheider et al. 2017; Thom et al. 2018); they can reveal how current decisions influence the future management options and flexibility to react to environmental changes. The results of the presented study showed that continuous forest interventions can transform secondary spruce stands into mixed mountain forests which are in a steady state in terms of stem diameter and tree species distribution. Of the investigated scenarios, we consider the ones with gaps or slit cuts to have the most beneficial overall utility values for the portfolio of five evaluation criteria. If timber production is not a management goal, and the focus is on nature conservation, the do-nothing regimes turned out to be a possible solution. However, it was not the aim of this study to present the 'best' management regime in mountain forests, but to exemplify and demonstrate the evaluation of management options with regard to related trade-offs between evaluation criteria.

Given that mountain forest management is highly cost and labour intensive (Valente et al. 2014; Jandl et al. 2018), spatially explicit simulation models can help to evaluate silvicultural practices which have not yet been sufficiently tested in practice, even if they may not be able to reproduce future developments in detail. However, with our results, we have showed that it is possible, by means of several trajectories, to return destabilised forests to sustainable, stable but managed systems. They showed that a transformation is realistic, even if sophisticated silvicultural concepts are 
not strictly pursued. In order to suffer fewer human casualties and less economic damage in the future, transformation efforts of destabilised forests should therefore be pursued worldwide.

Acknowledgements Open Access funding provided by Projekt DEAL. We would like to thank the Bayerische Staatsforsten (BaySF) for providing the experimental plots and to the Bavarian State Ministry of Food, Agriculture, and Forestry for permanent support of the Project W 07 'Long-term experimental plots for forest growth and yield research' (\#7831-26625-2017). Furthermore, we would like to thank the Bavarian State Institute of Forestry (LWF) for providing the timber prices. The authors would like to acknowledge networking support by the COST (European Cooperation in Science and Technology) Action CLIMO Forestry (Climate-Smart Forestry in Mountain RegionsCA15226) financially supported by the EU Framework Programme for Research and Innovation HORIZON 2020. This publication has received funding from the European Union's HORIZON 2020 research and innovation programme under the Marie Skłodowska-Curie grant agreement No 778322. We finally thank two anonymous reviewers for their constructive criticism.

Funding TH received scholarship from the Rudolf and Helene Glaser Foundation organised in the 'Stifterverband für die deutsche Wissenschaft'.

\section{Compliance with ethical standards}

Conflict of interest The authors declared that they have no conflict of interest.

Open Access This article is licensed under a Creative Commons Attribution 4.0 International License, which permits use, sharing, adaptation, distribution and reproduction in any medium or format, as long as you give appropriate credit to the original author(s) and the source, provide a link to the Creative Commons licence, and indicate if changes were made. The images or other third party material in this article are included in the article's Creative Commons licence, unless indicated otherwise in a credit line to the material. If material is not included in the article's Creative Commons licence and your intended use is not permitted by statutory regulation or exceeds the permitted use, you will need to obtain permission directly from the copyright holder. To view a copy of this licence, visit http://creativecommons.org/licenses/by/4.0/.

\section{References}

Acevedo MF, Urban DL, Shugart HH (1996) Models of forest dynamics based on roles of tree species. Ecol Model 87:267-284. https ://doi.org/10.1016/0304-3800(94)00208-8

Altieri V, De Franco S, Lombardi F et al (2018) The role of silvicultural systems and forest types in preventing soil erosion processes in mountain forests: a methodological approach using cesium-137 measurements. J Soils Sediments 18:3378-3387. https://doi. org/10.1007/s11368-018-1957-8

Ammer C (1996) Impact of ungulates on structure and dynamics of natural regeneration of mixed mountain forests in the Bavarian Alps. For Ecol Manag 88(1-2):43-53

Bauhus J, Forrester DI, Gardiner B et al (2017) Ecological Stability of Mixed-Species Forests. In: Pretzsch H, Forrester DI, Bauhus J (eds) Mixed-species forests: ecology and management. Springer, Berlin, pp 337-382
Bayer D, Pretzsch H (2017) Reactions to gap emergence: Norway spruce increases growth while European beech features horizontal space occupation-evidence by repeated 3D TLS measurements. Silva Fenn 51(5):7748

Bayerische Staatsforsten AöR (ed) (2018) Waldbauhandbuch Bayerische Staatsforsten. Richtlinie für die Waldbewirtschaftung im Hochgebirge

Beljan K, Posavec S, Čavlović J et al (2018) Economic consequences of different management approaches to even-aged silver fir forests. Croat J For Eng J Theory Appl For Eng 39:299-312

Bircher N, Cailleret M, Zingg A, Bugmann H (2016) Potenzielle Grundflächenveränderungen auf Bestandesebene im Klimawandel. In: Pluess AR, Augustin S, Brang P (eds) Wald im Klimawandel-Grundlagen für Adaptionsstrategien. Haupt, Bern, pp 157-171

Blennow K, Persson J, Tomé M, Hanewinkel M (2012) Climate change: believing and seeing implies adapting. PLoS ONE 7:e50182. https://doi.org/10.1371/journal.pone.0050182

Brang P, Schönenberger W, Frehner M et al (2006) Management of protection forests in the European Alps: an overview. For Snow Landsc Res 22:23-44

Bravo-Oviedo A, Pretzsch H, del Río M (2018) Dynamics, silviculture and management of mixed forests. Springer, Berlin

Briner S, Elkin C, Huber R (2013) Evaluating the relative impact of climate and economic changes on forest and agricultural ecosystem services in mountain regions. J Environ Manag 129:414-422. https://doi.org/10.1016/j.jenvman.2013.07.018

Brunner A, Hahn K, Biber P, Skovsgaard JP (2006) Conversion of Norway spruce: a case study in Denmark based on silvicultural scenario modelling. Sustainable forest management. Springer, Berlin, pp 343-371

Buma B, Wessman CA (2013) Forest resilience, climate change, and opportunities for adaptation: a specific case of a general problem. For Ecol Manag 306:216-225. https://doi.org/10.1016/j. foreco.2013.06.044

Ciancio O, Iovino F, Menguzzato G et al (2006) Structure and growth of a small group selection forest of calabrian pine in Southern Italy: a hypothesis for continuous cover forestry based on traditional silviculture. For Ecol Manag 224:229-234. https://doi. org/10.1016/j.foreco.2005.12.057

CIPRA (2007) Appell für eine zukunftsfähige Entwicklung der Bergwälder. Commission Internationale pour la Protection des Alpes. http://www.cipra.org. Accessed 28 Nov 2018

Cordonnier T, Courbaud B, Berger F, Franc A (2008) Permanence of resilience and protection efficiency in mountain Norway spruce forest stands: a simulation study. For Ecol Manag 256:347354. https://doi.org/10.1016/j.foreco.2008.04.028

Dieler J, Uhl E, Biber P et al (2017) Effect of forest stand management on species composition, structural diversity, and productivity in the temperate zone of Europe. Eur J For Res 136:739-766. https://doi.org/10.1007/s10342-017-1056-1

Dorren LKA, Berger F, Imeson AC et al (2004) Integrity, stability and management of protection forests in the European Alps. For Ecol Manag 195:165-176. https://doi.org/10.1016/j.forec o.2004.02.057

Drever CR, Peterson G, Messier C et al (2006) Can forest management based on natural disturbances maintain ecological resilience? Can J For Res 36:2285-2299. https://doi.org/10.1139/ $\mathrm{x} 06-132$

EEA (2010) Europe's ecological backbone: recognising the true value of our mountains. European Environmental Agency, Copenhagen

Ellenberg H (1988) Vegetation ecology of Central Europe, 4th edn. Cambridge University Press, Cambridge

Elling W, Dittmar C, Pfaffelmoser K, Rötzer T (2009) Dendroecological assessment of the complex causes of decline and recovery of 
the growth of silver fir (Abies alba Mill.) in Southern Germany. For Ecol Manag 257(4):1175-1187

Erb K-H, Kastner T, Plutzar C et al (2018) Unexpectedly large impact of forest management and grazing on global vegetation biomass. Nature 553:73-76. https://doi.org/10.1038/nature25138

Fleischer P, Fleischer P, Ferenčík J et al (2016) Elevated bark temperature in unremoved stumps after disturbances facilitates multivoltinism in Ips typographus population in a mountainous forest. For J 62:15-22. https://doi.org/10.1515/forj-2016-0002

Forest Europe (2011) State of Europe's forests 2011. Status and rends in sustainable forest management in Europe. In: Ministerial conference on the protection of forests in Europe

Forrester DI, Albrecht AT (2014) Light absorption and light-use efficiency in mixtures of Abies alba and Picea abies along a productivity gradient. For Ecol Manag 328:94-102

Goisser M, Geppert U, Rötzer T, Paya A, Huber A, Kerner R, Bauerle T, Pretzsch H, Pritsch K, Häberle KH, Matyssek R, Grams TEE (2016) Does belowground interaction with Fagus sylvatica increase drought susceptibility of photosynthesis and stem growth in Picea abies? For Ecol Manag 375:268-278

Hanewinkel M (2001) Economic aspects of the transformation from even-aged pure stands of Norway spruce to uneven-aged mixed stands of Norway spruce and beech. For Ecol Manag 151:181193. https://doi.org/10.1016/S0378-1127(00)00707-6

Hanewinkel M, Pretzsch H (2000) Modelling the conversion from even-aged to uneven-aged stands of Norway spruce (Picea abies L. Karst.) with a distance-dependent growth simulator. For Ecol Manag 134:55-70. https://doi.org/10.1016/S0378 $-1127(99) 00245-5$

Häyhä T, Franzese PP, Paletto A, Fath BD (2015) Assessing, valuing, and mapping ecosystem services in Alpine forests. Ecosyst Serv 14:12-23. https://doi.org/10.1016/j.ecoser.2015.03.001

Hetsch S (2008) Potential sustainable wood supply in Europe. Discussion Paper 53, Geneva

Hilmers T, Friess N, Bässler C et al (2018) Biodiversity along temperate forest succession. J Appl Ecol 55:2756-2766. https://doi. org/10.1111/1365-2664.13238

Hilmers T, Avdagić A, Bartkowicz L et al (2019) The productivity of mixed mountain forests comprised of Fagus sylvatica, Picea abies, and Abies alba across Europe. Forestry (Lond). https://doi. org/10.1093/forestry/cpz035

Hlásny T, Barka I, Roessiger J et al (2017) Conversion of Norway spruce forests in the face of climate change: a case study in Central Europe. Eur J For Res 136:1013-1028. https://doi. org/10.1007/s10342-017-1028-5

Hlásny T, Krokene P, Liebhold A et al (2019) Living with bark beetles: impacts, outlook and management options. European Forest Institute, Joensuu

Hoen HF, Solberg B (1994) Potential and economic efficiency of carbon sequestration in forest biomass through silvicultural management. For Sci 40:429-451. https://doi.org/10.1093/forestscie nce/40.3.429

Irauschek F, Rammer W, Lexer MJ (2017) Can current management maintain forest landscape multifunctionality in the Eastern Alps in Austria under climate change? Reg Environ Change 17:33-48. https://doi.org/10.1007/s10113-015-0908-9

Jactel $\mathrm{H}$ et al (2009) The influences of forest stand management on biotic and abiotic risks of damage. Ann For Sci 66:701. https:// doi.org/10.1051/forest/2009054

Jandl N, Jandl R, Schindlbacher A (2018) Future management options for cembran pine forests close to the alpine timberline. Ann For Sci 75:81. https://doi.org/10.1007/s13595-018-0760-4

Jensen AM (1983) Growth of Silver fir (Abies alba Mill.) compared with the growth of Norway spruce (Picea abies (L) Karst.) in pure and mixed stands on sandy soils in the western parts of
Denmark. Department of Forestry, Royal Veterinary Agricultural University, Rep 14

Jönsson AM, Harding S, Bärring L, Ravn HP (2007) Impact of climate change on the population dynamics of Ips typographus in southern Sweden. Agric For Meteorol 146:70-81. https://doi. org/10.1016/j.agrformet.2007.05.006

Jucker T, Bouriaud O, Coomes DA (2015) Crown plasticity enables trees to optimize canopy packing in mixed-species forests. Funct Ecol 29(8):1078-1086

Kimmins J, Blanco JA (2011) Issues facing forest management in Canada, and predictive ecosystem management tools for assessing possible futures. Landscape ecology in forest management and conservation. Higher Education Press/Springer, Bejing/Berlin, pp 46-72

Klein T (2014) The variability of stomatal sensitivity to leaf water potential across tree species indicates a continuum between isohydric and anisohydric behaviours. Funct Ecol 28(6):1313-1320

Klein D, Höllerl S, Blaschke M, Schulz C (2013) The contribution of managed and unmanaged forests to climate change mitigation-a model approach at stand level for the main tree species in Bavaria. Forests 4:43-69. https://doi.org/10.3390/f4010043

Knoke T, Plusczyk N (2001) On economic consequences of transformation of a spruce (Picea abies (L.) Karst.) dominated stand from regular into irregular age structure. For Ecol Manag 151:163-179. https://doi.org/10.1016/S0378-1127(00)00706-4

Knoke T, Moog M, Plusczyk N (2001) On the effect of volatile stumpage prices on the economic attractiveness of a silvicultural transformation strategy. For Policy Econ 2:229-240. https://doi. org/10.1016/S1389-9341(01)00030-2

Knoke T, Ammer C, Stimm B, Mosandl R (2008) Admixing broadleaved to coniferous tree species: a review on yield, ecological stability and economics. Eur J For Res 127:89-101. https://doi. org/10.1007/s10342-007-0186-2

Knoke T, Bendix J, Pohle P et al (2014) Afforestation or intense pasturing improve the ecological and economic value of abandoned tropical farmlands. Nat Commun 5:5612. https://doi. org/10.1038/ncomms6612

Koschke L, Fürst C, Frank S, Makeschin F (2012) A multi-criteria approach for an integrated land-cover-based assessment of ecosystem services provision to support landscape planning. Ecol Indic 21:54-66. https://doi.org/10.1016/j.ecolind.2011.12.010

Langner A, Irauschek F, Perez S et al (2017) Value-based ecosystem service trade-offs in multi-objective management in European mountain forests. Ecosyst Serv 26:245-257. https://doi. org/10.1016/j.ecoser.2017.03.001

Larsen JB, Yang WV, Tiedemann AV (1990) Effects of ozone on gas exchange, frost resistance, flushing and growth of different provenances of European silver fir (Abies alba Mill.). Eur J For Pathol 20(4):211-218

Lebourgeois F, Gomez N, Pinto P, Mérian P (2013) Mixed stands reduce Abies alba tree-ring sensitivity to summer drought in the Vosges mountains, western Europe. For Ecol Manag 303:61-71

Leitinger G, Meusburger K, Rüdisser J et al (2018) Spatial evaluation of snow gliding in the Alps. CATENA 165:567-575. https://doi. org/10.1016/j.catena.2018.03.001

Lemm R, Holm S, Thees O (2013) Bessere Produktions- und Nutzungsentscheide mit dem Sortierungssimulator SorSim. Schweiz Z Forstwes 164:301-309. https://doi.org/10.3188/szf.2013.0301

Leuschner C (2009) Die Trockenheitsempfindlichkeit der Rotbuche vor dem Hintergrund des prognostizierten Klimawandels. Jahrbuch der Akademie der Wissenschaften zu Göttingen, pp 281-296

Lévesque M, Saurer M, Siegwolf R et al (2013) Drought response of five conifer species under contrasting water availability suggests high vulnerability of Norway spruce and European larch. Glob Change Biol 19:3184-3199. https://doi.org/10.1111/gcb.12268 
Lexer MJ, Hönninger K, Scheifinger H et al (2002) The sensitivity of Austrian forests to scenarios of climatic change: a large-scale risk assessment based on a modified gap model and forest inventory data. For Ecol Manag 162:53-72. https://doi.org/10.1016/S0378 $-1127(02) 00050-6$

Löf M, Bergquist J, Brunet J et al (2010) Conversion of Norway spruce stands to broadleaved woodland-regeneration systems, fencing and performance of planted seedlings. Ecol Bull 53:165-174

Lyr H, Fiedler HJ, Tranquillini W (1992) Physiologie und Ökologie der Gehölze. G. Fischer Verlag, Jena

Magin R (1959) Struktur und Leistung mehrschichtiger Mischwälder in den bayerischen Alpen. Mitt Staatsforstverwaltung Bayerns, vol 30

Marini L, Ayres MP, Battisti A, Faccoli M (2012) Climate affects severity and altitudinal distribution of outbreaks in an eruptive bark beetle. Clim Change 115:327-341. https://doi.org/10.1007/ s10584-012-0463-Z

Matulla C, Groll N, Kromp-Kolb H et al (2002) Climate change scenarios at Austrian National Forest Inventory sites. Clim Res 22:161-173

Matyssek R, Wieser G, Ceulemans R, Rennenberg H, Pretzsch H, Haberer K, Oßwald W (2010) Enhanced ozone strongly reduces carbon sink strength of adult beech (Fagus sylvatica)-Resume from the free-air fumigation study at Kranzberg Forest. Environ Pollut 158(8):2527-2532

McCarthy J (2001) Gap dynamics of forest trees: a review with particular attention to boreal forests. Environ Rev 9:1-59. https:// doi.org/10.1139/a00-012

MCPFE (1993) Resolution H1: general guidelines for the sustainable management of forests in Europe. In: Proceedings of the 2nd ministerial conference on the protection of forests in Europe. Helsinki, Finland

Messerer K, Pretzsch H, Knoke T (2017) A non-stochastic portfolio model for optimizing the transformation of an even-aged forest stand to continuous cover forestry when information about return fluctuation is incomplete. Ann For Sci 74:45. https://doi. org/10.1007/s13595-017-0643-0

Mina M, Bugmann H, Cordonnier T et al (2017) Future ecosystem services from European mountain forests under climate change. $\mathrm{J}$ Appl Ecol 54:389-401. https://doi.org/10.1111/1365-2664.12772

Mina M, Huber MO, Forrester DI, Thürig E, Rohner B (2018) Multiple factors modulate tree growth complementarity in central European mixed forests. J Ecol 106:1106-1119

Moning C, Müller J (2008) Environmental key factors and their thresholds for the avifauna of temperate montane forests. For Ecol Manag 256:1198-1208. https://doi.org/10.1016/j.forec o.2008.06.018

Moos C, Bebi P, Schwarz M et al (2018) Ecosystem-based disaster risk reduction in mountains. Earth Sci Rev 177:497-513. https://doi. org/10.1016/j.earscirev.2017.12.011

Morin X, Fahse L, de Mazancourt C et al (2014) Temporal stability in forest productivity increases with tree diversity due to asynchrony in species dynamics. Ecol Lett 17:1526-1535. https://doi. org/10.1111/ele.12357

Mosandl R (1984) Löcherhiebe im Bergmischwald: ein waldbauökologischer Beitrag zur Femelschlagverjüngung in den Chiemgauer Alpen. Frank, München

Nabuurs GJ, Thürig E, Heidema N et al (2008) Hotspots of the European forests carbon cycle. For Ecol Manag 256:194-200. https ://doi.org/10.1016/j.foreco.2008.04.009

Naudts K, Chen Y, McGrath MJ, Ryder J, Valade A, Otto J, Luyssaert $S$ (2016) Europe's forest management did not mitigate climate warming. Science (New York, N.Y.) 351(6273):S597-S600. https://doi.org/10.1126/science.aad7270

Niedertscheider M, Tasser E, Patek M et al (2017) Influence of landuse intensification on vegetation C-stocks in an Alpine Valley from 1865 to 2003. Ecosystems 20:1391-1406. https://doi. org/10.1007/s10021-017-0120-5

Nikolova PS, Raspe S, Andersen CP, Mainiero R, Blaschke H, Matyssek R, Häberle KH (2009) Effects of the extreme drought in 2003 on soil respiration in a mixed forest. Eur J For Res 128(2):87-98

O'Hara KL (2001) The silviculture of transformation-a commentary. For Ecol Manag 151:81-86. https://doi.org/10.1016/S0378 -1127(00)00698-8

Offenthaler I, Hochbichler E (2006) Estimation of root biomass of Austrian forest tree species. Austrian J For Sci 1:65-86

Paillet Y, Bergès L, Hjältén J et al (2010) Biodiversity differences between managed and unmanaged forests: meta-analysis of species richness in Europe. Conserv Biol 24:101-112. https://doi. org/10.1111/j.1523-1739.2009.01399.x

Panagos P, Borrelli P, Poesen J et al (2015) The new assessment of soil loss by water erosion in Europe. Environ Sci Policy 54:438-447. https://doi.org/10.1016/j.envsci.2015.08.012

Pepin N, Diaz HF, Baraer M et al (2015) Elevation-dependent warming in mountain regions of the world. Nat Clim Change 5:424-430. https://doi.org/10.1038/nclimate2563

Porta NL, Capretti P, Thomsen IM et al (2008) Forest pathogens with higher damage potential due to climate change in Europe. Can J Plant Pathol 30:177-195. https://doi.org/10.1080/07060 661.2008.10540534

Preuhsler T (1979) Ertragskundliche Merkmale oberbayerischer Bergmischwald-Verjüngungsbestände auf kalkalpinen Standorten im Forstamt Kreuth. Forstl Forschungsber München 45, 372 p

Pretzsch H (1997) Analysis and modeling of spatial stand structures. Methodological considerations based on mixed beech-larch stands in Lower Saxony. For Ecol Manag 97:237-253. https:// doi.org/10.1016/S0378-1127(97)00069-8

Pretzsch H (2009) Forest dynamics, growth and yield. Springer, Berlin, p 664

Pretzsch H (2019) Grundlagen der Waldwachstumsforschung, 2nd edn. Springer Spektrum, Heidelberg

Pretzsch H, Forrester DI (2017) Stand dynamics of mixed-species stands compared with monocultures. In: Pretzsch H, Forrester DI, Bauhus J (eds) Mixed-species forests. Springer, Berlin, pp 117-210. https://doi.org/10.1007/978-3-662-54553-9_5

Pretzsch H, Kahn M (1996) Wuchsmodelle für die Unterstützung der Wirtschaftsplanung im Forstbetrieb. AFZ Der Wald 51:1414

Pretzsch H, Biber P, Durský J (2002) The single tree-based stand simulator SILVA: construction, application and evaluation. For Ecol Manag 162:3-21. https://doi.org/10.1016/S0378-1127(02)00047 $-6$

Pretzsch H, Block J, Dieler J, Dong PH, Kohnle U, Nagel J, Spellmann $\mathrm{H}$, Zingg A (2010) Comparison between the productivity of pure and mixed stands of Norway spruce and European beech along an ecological gradient. Ann For Sci 67(7):712

Pretzsch H, Block J, Dieler J et al (2014) Nährstoffentzüge durch die Holz-und Biomassenutzung in Wäldern. Teil 1: schätzfunktionen für Biomasse und Nährelemente und ihre Anwendung in Szenariorechnungen. Allg Forst u J-Ztg 185:261-285

Pretzsch H, Biber P, Uhl E, Dauber E (2015) Long-term stand dynamics of managed spruce-fir-beech mountain forests in Central Europe: structure, productivity and regeneration success. Forestry (Lond) 88:407-428. https://doi.org/10.1093/forestry/cpv013

Prodan M (1944) Zuwachs-und Ertragsuntersuchungen im Plenterwalde: ein Beitrag zur Methodik der Ertragsuntersuchungen im Plenterwalde, dargelegt anhand der Ergebnisse der badischen Plenterwaldversuchsflächen. Ph.D. Thesis, Universität Freiburg

R Core Team (2018) R: a language and environment for statistical computing. R Foundation for Statistical Computing, Vienna

Rammer W, Brauner M, Ruprecht H, Lexer MJ (2015) Evaluating the effects of forest management on rockfall protection and timber 
production at slope scale. Scand J For Res 30:719-731. https:// doi.org/10.1080/02827581.2015.1046911

Reininger H (2000) Plenterprinzip, oder, die Überführung des Altersklassenwaldes. Stocker, Tangier

Roessiger J, Griess VC, Knoke T (2011) May risk aversion lead to nearnatural forestry? A simulation study. Forestry (Lond) 84:527537. https://doi.org/10.1093/forestry/cpr017

Roessiger J, Griess VC, Härtl F et al (2013) How economic performance of a stand increases due to decreased failure risk associated with the admixing of species. Ecol Model 255:58-69. https ://doi.org/10.1016/j.ecolmodel.2013.01.019

Röhle H (1995). Zum Wachstum der Fichte auf Hochleistungsstandorten in Südbayern. Bayerisches Staatsministerium für Ernährung, Landwirtschaft und Forsten, Referat Forstliche Ausund Fortbildung 48

Rothe A (1997) Einfluß des Baumartenanteils auf Durchwurzelung, Wasserhaushalt, Stoffhaushalt und Zuwachsleistung eines Fichten-Buchen-Mischbestandes am Standort Höglwald. Forstl Forschungsber München, vol 163

Rothe A, Binkley D (2001) Nutritional interactions in mixed species forests: a synthesis. Can J For Res 31(11):1855-1870

Rötzer T, Biber P, Moser A, Schäfer C, Pretzsch H (2017) Stem and root diameter growth of European beech and Norway spruce under extreme drought. For Ecol Manag 406:184-195

Schelhaas M-J, Nabuurs G-J, Hengeveld G et al (2015) Alternative forest management strategies to account for climate changeinduced productivity and species suitability changes in Europe. Reg Environ Change 15:1581-1594. https://doi.org/10.1007/ s10113-015-0788-z

Schmid I, Kazda M (2002) Root distribution of Norway spruce in monospecific and mixed stands on different soils. For Ecol Manag 159(1-2):37-47

Seidl R, Rammer W, Jäger D et al (2007) Assessing trade-offs between carbon sequestration and timber production within a framework of multi-purpose forestry in Austria. For Ecol Manag 248:64-79. https://doi.org/10.1016/j.foreco.2007.02.035

Seidl R, Rammer W, Lexer MJ (2011) Adaptation options to reduce climate change vulnerability of sustainable forest management in the Austrian Alps. Can J For Res 41:694-706. https://doi. org $/ 10.1139 / \times 10-235$

Seidl R, Schelhaas M-J, Rammer W, Verkerk PJ (2014) Increasing forest disturbances in Europe and their impact on carbon storage. Nat Clim Change 4:806-810. https://doi.org/10.1038/nclim ate 2318

Seidl R, Aggestam F, Rammer W et al (2016) The sensitivity of current and future forest managers to climate-induced changes in ecological processes. Ambio 45:430-441. https://doi.org/10.1007/ s13280-015-0737-6

Seidl R, Albrich K, Erb K et al (2019) What drives the future supply of regulating ecosystem services in a mountain forest landscape? For Ecol Manag 445:37-47. https://doi.org/10.1016/j. foreco.2019.03.047

Sikkema R, Steiner M, Junginger M, Hiegl W, Tony MH, Faaij A (2011) The European wood pellet markets: current status and prospects for 2020. Biofuels Bioprod Bioref 5(3):S250-S278. https://doi.org/10.1002/bbb.277
Spiecker H (2000) Growth of Norway Spruce (Picea abies (L.) Karst.) under changing environmental conditions in Europe. In: Klimo E, Hager H, Kulhavy J (eds) Spruce monocultures in Central Europe: problems and prospects. European Forest Institute, vol 33. European Forest Institute Proceedings, pp 11-26

Spiecker H, Hansen J, Klimo E et al (2004) Norway spruce conversion: options and consequences. Brill, Leiden

Streit K, Wunder J, Brang P (2009) Slit-shaped gaps are a successful silvicultural technique to promote Picea abies regeneration in mountain forests of the Swiss Alps. For Ecol Manag 257:19021909. https://doi.org/10.1016/j.foreco.2008.12.018

Thom D, Rammer W, Garstenauer R, Seidl R (2018) Legacies of past land use have a stronger effect on forest carbon exchange than future climate change in a temperate forest landscape. Biogeosciences 15:5699-5713. https://doi.org/10.5194/ bg-15-5699-2018

Valente C, Spinelli R, Hillring BG (2011) LCA of environmental and socio-economic impacts related to wood energy production in alpine conditions: Valle di Fiemme (Italy). J Clean Prod 19:1931-1938. https://doi.org/10.1016/j.jclepro.2011.06.026

Valente C, Spinelli R, Hillring BG, Solberg B (2014) Mountain forest wood fuel supply chains: comparative studies between Norway and Italy. Biomass Bioenergy 71:370-380. https://doi. org/10.1016/j.biombioe.2014.09.018

Vallet P, Pérot T (2011) Silver fir stand productivity is enhanced when mixed with Norway spruce: evidence based on large-scale inventory data and a generic modelling approach. J Veg Sci 22(5):932-942

Vitkova L, Dhubháin ÁN (2013) Transformation to continuous cover forestry-a review. Irish For 70:119-140

Weibull W (1951) A statistical distribution of wide applicability. J Appl Mech 103:293-297

Weisser WW, Siemann E (2013) Insects and ecosystem function. Springer, Berlin

Wermelinger B (2004) Ecology and management of the spruce bark beetle Ips typographus-a review of recent research. For Ecol Manag 202(1-3):67-82

Wickham H, François R, Henry L, Müller K (2018) dplyr: a grammar of data manipulation

Yousefpour R, Temperli C, Jacobsen JB et al (2017) A framework for modeling adaptive forest management and decision making under climate change. Ecol Soc. https://doi.org/10.5751/ ES-09614-220440

Zang C, Hartl-Meier C, Dittmar C et al (2014) Patterns of drought tolerance in major European temperate forest trees: climatic drivers and levels of variability. Glob Change Biol 20:3767-3779. https ://doi.org/10.1111/gcb.12637

Zenner EK, Peck JE, Hobi ML, Commarmot B (2016) Validation of a classification protocol: meeting the prospect requirement and ensuring distinctiveness when assigning forest development phases. Appl Veg Sci 19:541-552. https://doi.org/10.1111/ avsc. 12231

Publisher's Note Springer Nature remains neutral with regard to jurisdictional claims in published maps and institutional affiliations. 